\title{
Interactions of Escherichia coli and Proteus mirabilis with mouse mononuclear phagocytes
}

\author{
C. L. WELLS*†, R. P. JECHOREK† and R. D. NELSON $\ddagger$
}

Departments of *Laboratory Medicine and Pathology, †Surgery and $\ddagger$ Dermatology, Box 198, Mayo Building, University of Minnesota, Minneapolis, MN55455, USA

\begin{abstract}
Summary. Five strains of enterobacteria (three of Escherichia coli and two of Proteus mirabilis) were studied to assess and compare their phagocytic uptake and intracellular killing by mouse macrophages. Each strain was injected intraperitoneally into separate groups of mice and peritoneal exudate cells were harvested after $3 \mathrm{~min}$ for phagocytosis to occur in vivo. Acridine orange staining showed that there were approximately 10 -fold fewer intracellular $P$. mirabilis than $E$. coli cells. The average numbers of viable intracellular bacteria per leucocyte were 0.03 and 0.02 for $P$. mirabilis strains $\mathrm{M} 13$ and $\mathrm{H} 1$, respectively, and $0 \cdot 48,0 \cdot 45$, and $0 \cdot 28$ for $E$. coli strains M14, A-D M5 and H40. Thus, both $P$. mirabilis strains were ingested less readily than any of the three $E$. coli strains $(\mathrm{p}<0.01)$. The rates of in-vitro intracellular killing were similar for all five strains of bacteria. The intracellular killing constants $\left(\mathrm{K}_{\mathrm{k}}\right)$ for the three mouse isolates were $0.017,0.016$ and $0.020 \mathrm{~min}$ for $E$. coli M14 and A-D M5, and $P$. mirabilis M13, respectively; the $\mathrm{K}_{\mathrm{k}} \mathrm{s}$ for the two human isolates were 0.026 and $0.029 / \mathrm{min}$ for $E$. coli $\mathrm{H} 40$ and $P$. mirabilis $\mathrm{H} 1$, respectively. The $\mathrm{K}_{\mathrm{k}}$ s for all five strains were not significantly different. Assuming that the numbers of viable intracellular bacteria at the beginning of the assay represented $100 \%$ viability, $6-17 \%$ of the intracellular bacteria remained viable after $2 \mathrm{~h}$, reflecting $\log _{10} 3.9-5.6$ bacteria $(6-8) \times 10^{6}$ peritoneal exudate cells. Intravenous injection of these five strains into separate groups of mice demonstrated that the $P$. mirabilis strains were more virulent than the $E$. coli strains. Injection of each $P$. mirabilis strain was associated with ruffled fur and death, whereas mice given any of the three $E$. coli strains remained visibly healthy and none died. Consistent with these observations, quantitation of viable bacteria in the liver and spleen showed that greater numbers of $P$. mirabilis M13 than of $E$. coli M14 or A-D M5 persisted in these organs; similarly greater numbers of $P$. mirabilis $\mathrm{H} 1$ than of $E$. coli $\mathrm{H} 40$ persisted in the liver and spleen. Because the rates of intracellular killing of these five strains were similar, the relative virulence of both strains of $P$. mirabilis appeared to be associated with decreased phagocytic uptake rather than differences in intracellular survival.
\end{abstract}

\section{Introduction}

Ingestion and killing of bacterial pathogens by tissue macrophages is a primary mechanism of host defence. It is well known that some relatively pathogenic bacterial species can resist intracellular killing and even replicate within tissue macrophages. Classical examples of these facultative intracellular pathogens include Listeria monocytogenes and Salmonella sp. ${ }^{1,2}$ Although these species are not considered to be members of the normal intestinal flora, it is well documented that they can

Received 14 Aug. 1989; revised version accepted 28 Feb. 1990. use the intestinal tract as a portal of entry to invade otherwise sterile tissues such as the liver and spleen. ${ }^{3}$ There is direct electronmicroscopic evidence that $L$. monocytogenes ${ }^{4}$ and Salmonella spp. ${ }^{5}$ can be exported from the intestinal tract within tissue phagocytes in the intestinal mucosa. We have postulated recently that, like Salmonella spp. and L. monocytogenes, intestinal bacteria such as Escherichia coli and Proteus sp. may translocate across the intestinal tract within mononuclear phagocytes. We have proposed that phagocytes transporting intestinal bacteria fail to accomplish intracellular killing and then liberate viable bacteria in an extraintestinal site. ${ }^{3,6}$ For macrophages to play an 
active role in the transport of intestinal bacteria, these bacteria must be capable of surviving within the phagocytes. The ability of mononuclear phagocytes to ingest and kill facultative pathogens such as L. monocytogenes and Salmonella spp. has been relatively well studied. However, there are comparatively few reports describing the uptake and killing of normal intestinal bacteria by mononuclear phagocytes.

The aim of the present study was to determine the ability of murine macrophages to ingest and kill five strains of normal enterobacteria-three $E$. coli strains and two $P$. mirabilis strains.

\section{Materials and methods}

\section{Mice, bacterial strains, and preparation of bacterial inocula}

Female, 20-24-g Swiss-Webster mice were used in all experiments. Five strains of bacteria in the family Enterobacteriaceae were examined; $E$. coli strains M14 and A-D M5 and $P$. mirabilis strain M13 were isolated from mouse caecal contents and $E$. coli $\mathrm{H} 40$ and $P$. mirabilis $\mathrm{H} 1$ were human clinical isolates. Each strain was identified by the API 20E system (Analytab Products, Plainview, NY). (E. coli A-D is a lactose-negative variant ${ }^{7}$ ). Each strain was grown in Brain Heart Infusion Broth (Difco) supplemented with glycerol $10 \%$ and frozen at $-70^{\circ} \mathrm{C}$ until needed for experiments. Overnight Tryptic Soy Broth (Difco) cultures of individual species were washed twice in sterile saline and resuspended to $c$. $10^{8}$ bacteria $/ \mathrm{ml}$ (determined by densitometry) in Hanks's Balanced Salts Solution (HBSS; Gibco) with gelatin $0 \cdot 1 \%$. The numbers of viable bacteria were confirmed by quantitative plating on to MacConkey agar containing lactose $10 \%$.

\section{Electronmicroscopy of bacterial cells}

Transmission electronmicroscopy of negatively stained cells was used to visualise the surface structures on the cells in the bacterial inocula described above. Bacterial cells were washed once, resuspended in normal saline, placed on carbon-coated Formvar grids for 30-90 s, negatively stained with $12 \mathrm{~mm}$ uranyl acetate containing bacitracin (Sigma) $50 \mu \mathrm{g} / \mathrm{ml}$ and $12 \mathrm{mM}$ oxalic acid (Sigma) at pH 6.6, and examined at $80 \mathrm{kV}$ with a Jeol $100 \mathrm{CX}$ transmission electronmicroscope.

\section{In-vivo phagocytic uptake and in-vitro intracellular killing of bacteria by mononuclear phagocytes}

Intracellular killing of bacteria was assessed by the method of Leijh et al. ${ }^{1}$ with minor modifications. Briefly, mice were given intraperitoneal (i.p.) injections of $1 \mathrm{ml}$ of Proteose Peptone (Difco) $10 \%$ in tap water; $48 \mathrm{~h}$ later, separate groups of 10-12 mice were given i.p. injections of $1 \mathrm{ml}$ of one of the five bacterial suspensions prepared as described above. The numbers of viable bacteria $/ \mathrm{ml}$ in these inocula were $\left(6 \times 10^{7}\right)-\left(1 \times 10^{8}\right)$. After $3 \mathrm{~min}(\mathrm{a}$ time corresponding to maximal phagocytic uptake ${ }^{1}$ ), mice were killed by cervical dislocation and $3 \mathrm{ml}$ of HBSS with heparin $1 \mathrm{U} / \mathrm{ml}$ were injected i.p. The abdominal cavity was gently massaged for $1 \mathrm{~min}$ and the peritoneal exudate cells were harvested into ice cold HBSS with gelatin $0.1 \%$, washed four times $(4 \mathrm{~min}, 110 \mathrm{~g})$ in the same medium, and resuspended to a concentration of (6$8) \times 10^{6} \mathrm{cells} / \mathrm{ml}$ in $6 \mathrm{ml}$. After the last wash, the numbers of bacteria in the supernatents were 10 -fold lower than the corresponding numbers of intracellular bacteria, indicating that the residual extracellular bacteria should not affect the subsequent quantitation of intracellular bacteria. As reported by other investigators, ${ }^{1,8}$ WrightGiemsa stain of cells prepared by cytospin centrifugation demonstrated that approximately $80 \%$ of the peritoneal exudate cells appeared to be macrophages. Viability of the peritoneal exudate cells was consistently $\geq 95 \%$ as determined by trypan blue dye exclusion. Washed peritoneal exudate cells were rotated at $4 \mathrm{rpm}$ at $37^{\circ} \mathrm{C}$ for a maximum of $120 \mathrm{~min}$. At various intervals, $0.5-\mathrm{ml}$ samples were removed and mixed with $0.5 \mathrm{ml}$ of ice cold HBSS, centrifuged for $4 \mathrm{~min}$ at $110 \mathrm{~g}$, and $1 \mathrm{ml}$ of bovine serum albumin (BSA) $0.01 \%$ in ice cold distilled water was added to the cell pellet. The cells were subjected to three freeze-thaw lysis cycles with liquid nitrogen and warm water $\left(37^{\circ} \mathrm{C}\right)$ and phagocyte lysis was verified microscopically. The numbers of viable intracellular bacteria were determined after serial dilution in phosphate buffered saline with gelatin $0.1 \%$ (PBSG), followed by plating on to MacConkey $10 \%$ lactose agar.

Phagocytic uptake was quantified by a method similar to that described by Ofek and Sharon. ${ }^{9}$ At the beginning of the assay for intracellular killing $(0 \mathrm{~min})$, the bacteriato-phagocyte ratio was determined by dividing the number of viable intracellular bacteria/ml by the total number of peritoneal exudate cells $/ \mathrm{ml}$.

Data were analysed by a one-way analysis of variance and then tested for least significant difference. The numbers of viable bacteria in the in-vitro intracellular killing assay were transformed to $\log _{10}$ values before statistical analysis. The rate constant $\left(\mathrm{K}_{\mathrm{k}}\right)$ for in-vitro intracellular killing was calculated according to Leijh $e t$ al. ${ }^{1}$ as: $\mathrm{K}_{\mathrm{k}}=\left[\ln \mathrm{N}_{(\mathrm{t}=0)}-\ln \mathrm{N}_{(\mathrm{t})}\right] / \mathrm{t}$. The data for in-vitro intracellular killing and in-vivo phagocytic uptake represent pooled data from 5-9 similar experiments performed on separate days. Each experiment included use of either all three mouse isolates (E. coli M14 and A-D M5, P. mirabilis M13) or both human isolates ( $E$. coli $\mathrm{H} 40, P$. mirabilis $\mathrm{H} 1$ ).

At the beginning and end of the in-vitro intracellular killing assay ( 0 and $120 \mathrm{~min}$ ), acridine orange stains of intact leucocytes (prior to lysis) were viewed and photographed by fluorescence microscopy to assess visually the viability of intracellular bacteria. With this methodology, viable bacteria fluoresce green and nonviable bacteria appear yellow-green to yellow to red $;^{10}$ 
only brilliant apple green bacteria were considered to be viable, and bacteria with even slight shades of yellow were considered to be non-viable. To present the results of the acridine orange stain optimally, a representative colour transparency was subjected to computer image analysis. With a Dage-MIT series 68 Newvicon ${ }^{\circledR}$ camera, the colour transparency was displayed on a television monitor and the video image was digitalised with an image processing system (System S75 software; International Imaging Systems) and stored as an eight-bit, $512 \times$ 512 pixel image in the frame buffer memory of a Masscomp MC 5500 minicomputer. This image was transferred to an Iris 2400 Turbo Work Station monitor and photographed from the screen on to Kodak Professional Copy Film. With this technique, fluorescent green (viable) bacteria have a dull appearance, whereas yellowgreen to red (nonviable) bacteria are noticeably brighter.

\section{In-vivo clearance of bacteria by the kidneys, spleen and liver}

Separate groups of 20 mice were given intravenous (i.v., tail vein) injections of one of the five test strains suspended in $0.25 \mathrm{ml}$ of sterile saline. Each inoculum was prepared as described above and the total number of viable bacteria suspended in $0.25 \mathrm{ml}$ sterile saline was $(1-5) \times 10^{8}$. In each of two replicate experiments, four mice from each group were killed $15 \mathrm{~min}$ and 1, 4, 24 and $48 \mathrm{~h}$ after bacterial injection. The spleen, kidneys and liver were aseptically excised, in that order, for quantitation of viable bacteria. Kidneys (treated as one tissue) and spleen were separately homogenised in $2 \mathrm{ml}$ of PBSG and the liver was homogenised in $3 \mathrm{ml}$ of the same medium. Tissue homogenates were serially diluted in PBSG, planted on to MacConkey lactose agar and incubated at $35^{\circ} \mathrm{C}$ for $24-48 \mathrm{~h}$. Bacteria were counted as the total number of viable bacteria per tissue and these numbers were transformed to $\log _{10}$ values for statistical analysis by one-way analysis of variance followed by testing for least significant difference. The limits of detection of the assay were $\log _{10} 2 \cdot 0$ for the spleen and kidneys and $\log _{10} 2 \cdot 2$ for the liver; for the purpose of statistical analysis, values below the limit of detection of the assay were assigned a value of $\log _{10} 1.9$ for the spleen and kidneys and $\log _{10} 2 \cdot 1$ for the liver.

\section{Results}

\section{Electronmicroscopy of bacterial cells}

The table shows the types of surface appendages observed on the bacterial cells in the inocula used in these experiments. At least 200 cells of each strain were examined. All five strains had peritrichous flagella. Fimbriae were also easily detected on the two $P$. mirabilis strains. Fimbriae were never observed on $E$. coli A-D M5, but a sparse distribution of fimbriae was seen on occasional $(c .0 \cdot 5 \%)$ cells of $E$. coli M14 and H40.

\section{In-vivo phagocytic uptake of bacteria}

Three min after i.p. injection of $E$. coli strains M14, A-D M5 or H40, c. $25-50 \%$ of the harvested peritoneal exudate cells contained ingested bacteria, as viewed by acridine orange staining. These bacteria were unevenly distributed within individual phagocytes; $c .10 \%$ of the phagocytes contained many bacteria while the remainder contained few or no bacteria. At this time, virtually all intracellular

Table. Surface appendages, phagocytic indices and intracellular killing constants $\left(\mathrm{K}_{\mathrm{k}}\right)$ of $E$. coli strain M14, AD M5 and $\mathrm{H} 40$ and $P$. mirabilis strains $\mathrm{M} 13$ and $\mathrm{H} 1$

\begin{tabular}{|c|c|c|c|c|c|}
\hline Strain & Source & Flagella* & Fimbriae & $\begin{array}{c}\text { Phagocytic } \\
\text { index } \dagger\end{array}$ & $\underset{\text { mean }(\mathrm{SEM})}{\mathbf{K}_{\mathrm{k}}(\min ) \ddagger}$ \\
\hline E. coli $\mathrm{M} 14$ & Mouse & + & sparse & $0.48(0 \cdot 16)$ & $0.017(0.006)$ \\
\hline P. mirabilis M13 & Mouse & + & + & $0.03(0.01) \S$ & $0.020(0.003)$ \\
\hline E. coli A-D M5 & Mouse & + & - & $0.45(0.11)$ & $0.016(0.003)$ \\
\hline E. coli $\mathrm{H} 40$ & Man & + & sparse & $0 \cdot 28(0.06)$ & $0.026(0.009)$ \\
\hline P. mirabilis $\mathrm{H} 1$ & Man & + & + & $0.02(0.01) \S$ & $0.029(0.003)$ \\
\hline
\end{tabular}

* Peritrichous flagella were noted on $c .50 \%$ of the cells of each strain.

$\uparrow$ Number of viable intracellular bacteria/total number of peritoneal exudate cells after in-vivo phagocytosis for $3 \mathrm{~min}$.

$\ddagger$ The rates of intracellular killing for the three mouse isolates were similar, $p>0.50$. The rates of intracellular killing for the two human isolates were also similar, $\mathrm{p}>0.50$. No significant differences were noted when results with all five strains were compared simultaneously but individually ( $p>0 \cdot 1)$, but when the results obtained with the mouse isolates and the human isolates were pooled, the difference between the mouse and human isolates was significant $(\mathrm{p}<0 \cdot 05)$.

$\S$ Significantly reduced compared with each $E$. coli strain, $\mathrm{p}<0.01$. 
bacteria appeared to be viable (apple green fluorescence). Nomarski differential interference optics was used to verify the intracellular position of the bacteria. Consecutive examination of cells with Nomarski and epifluorescence revealed that the bacteria were in optimal focus when the leucocytes were optically sectioned through the cytoplasm; focusing at the apical or basal surface of the leucocytes, the image of the bacteria was out of focus. Approximately 10-fold fewer peritoneal exudate cells, harvested from mice given $P$. mirabilis M13 or H1, contained bacteria and the number of intracellular bacteria per leucocyte appeared to be reduced. As noted with the three $E$. coli strains, virtually all intracellular $P$. mirabilis appeared to be viable at this time, as determined by acridine orange staining. The average number of viable intracellular bacteria per leucocyte was determined for each of the five bacterial strains by plate counts. Consistent with the visual observations from the acridine orange stains, significantly lower bacteriato-leucocyte ratios were attained with the two $P$. mirabilis strains than with each of the three $E$. coli strains (table).

\section{In-vitro intracellular killing of E. coli $M 14$ and $A-D$} M5 and P. mirabilis M13

The results of the intracellular killing of $E$. coli M14 and A-D M5 and $P$. mirabilis M13 are presented in two ways in an attempt to clearly illustrate our interpretations of these data (fig. 1). At each time point throughout the 2-h assay (including $0 \mathrm{~min}$ ), there were fewer viable intracellular bacteria of $P$. mirabilis M13 than of E. coli M14 or A-D M5 ( $<<0.01$, fig. 1a), reflecting the lower numbers of intracellular $P$. mirabilis $\mathrm{M} 13$ present at the beginning of the assay. The three curves presented in fig. 1a appear to have similar slopes and the $\mathrm{K}_{\mathrm{k}} \mathrm{s}$ indicated that these three strains were killed intracellularly at similar rates (table). Fig. $1 \mathrm{~b}$ shows the intracellular killing of $E$. coli M14 and A-D M5 and $P$. mirabilis M13 expressed as the percentage of viable intracellular bacteria. Here, there appeared also to be no differences in the rates of intracellular killing of these strains; $14-17 \%$ of the intracellular $E$. coli M14 or A-D M5 or $P$. mirabilis M13 cells were viable at the end of the 2-h assay, representing substantial numbers of intracellular bacteria (fig. 1a).

The presence of viable intracellular bacteria at the conclusion of the assay was confirmed microscopically by observations of cells stained with acridine orange. Fig. 2 is a typical acridine orange stain of peritoneal exudate cells after incubation in
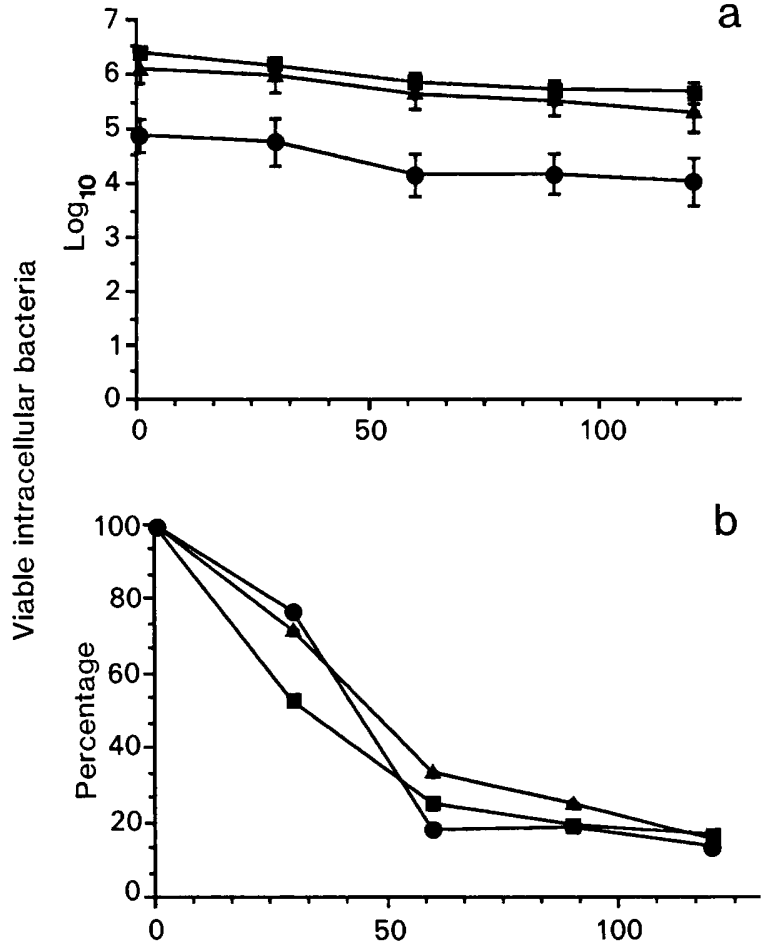

Time ( $\mathrm{min})$

Fig. 1. In vitro intracellular killing of E. coli M14 (A) and A-D M5 ( $\square$ ) and P. mirabilis M13 (O) at various times after in-vivo phagocytosis for $3 \mathrm{~min}$ by mouse peritoneal exudate cells. (a) Numbers of viable bacteria recovered from $(6-8) \times 10^{6}$ peritoneal exudate cells. (b) Percentage of viable intracellular bacteria (number of bacteria recovered at time $0=100 \%$ ). Results are expressed as means, $\mathrm{bar}=\mathrm{SEM}$.

vitro for $2 \mathrm{~h}$ with $E$. coli $\mathrm{M} 14$. It shows a peritoneal exudate cell with many viable intracellular bacteria. In most microscopic fields visualised, the majority of intracellular bacteria appeared dead at this time; however, microscopic fields similar to that shown in fig. 2 were not difficult to find. Similar observations were made with acridine-orange-stained preparations of peritoneal cells exposed for $2 \mathrm{~h}$ to $P$. mirabilis M13 and E. coli A-D M5.

\section{In-vitro intracellular killing of E. coli $\mathrm{H} 4 \mathrm{O}$ and $\mathrm{P}$. mirabilis $\mathrm{HI}$}

Results of in-vitro intracellular killing of $E$. coli $\mathrm{H} 40$ and $P$. mirabilis $\mathrm{H} 1$ are shown in fig. 3. The kinetics of intracellular killing of these two human isolates paralleled those obtained with the three mouse isolates. At each time point throughout the 2-h assay there were fewer viable intracellular $P$. 


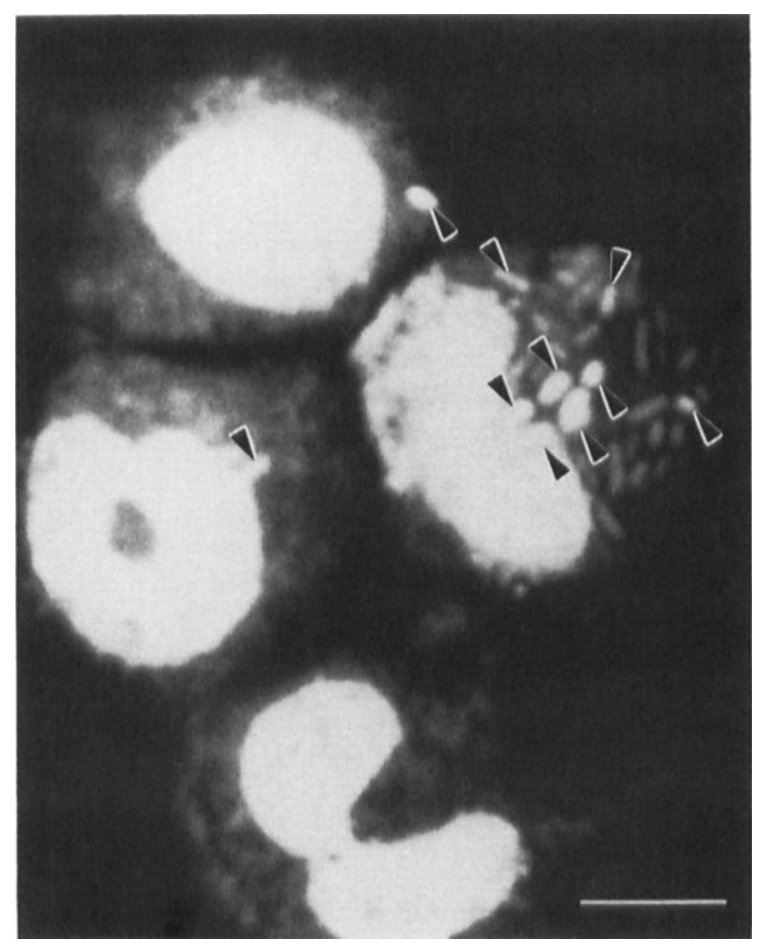

Fig. 2. Computer image analysis of acridine-orange-stained mouse peritoneal exudate cells after in-vivo phagocytosis of $E$. coli $\mathrm{Ml} 4$ for $3 \mathrm{~min}$, followed by $2 \mathrm{~h}$ of in-vitro incubation. Bacteria appear unevenly distributed within mononuclear phagocytes with $c$. 40 intracellular bacteria in one phagocyte (far right) and few or no bacteria in the remaining phagocytes. The non-viable bacteria appear swollen and brighter than the viable bacteria; the phagocyte on the far right contains nine non-viable bacteria (arrows) and at least 30 viable bacteria. Bar, $5 \mu \mathrm{m}$.

mirabilis $\mathrm{H} 1$ than E. coli $\mathrm{H} 40$ cells ( $<0.01$, fig. 3a), reflecting the lower number of intracellular $P$. mirabilis $\mathrm{H} 1$ recovered at the beginning of the assay. The $\mathrm{K}_{\mathrm{k}} \mathrm{s}$ of $E$. coli $\mathrm{H} 40$ and $P$. mirabilis $\mathrm{Hl}$ were also similar (table). Fig. $3 \mathrm{~b}$ shows the percentage of viable intracellular $E$. coli $\mathrm{H} 40$ and $P$. mirabilis $\mathrm{H} 1$ at various times during the $2-\mathrm{h}$ assay. Although only $5 \%$ of E. coli $\mathrm{H} 40$ and $17 \%$ of $P$. mirabilis $\mathrm{H} 1$ cells remained viable at the conclusion of the assay, these percentages reflected substantial numbers of bacteria (fig. 3a). Acridine orange staining of peritoneal exudate cells again demonstrated that viable intracellular bacteria were detected easily in percentages consistent with those presented in fig. $3 b$.

It should be noted (table) that the $\mathrm{K}_{\mathrm{k}} \mathrm{s}$ for the three mouse isolates (E. coli $\mathrm{M} 14$ and A-D M5, $P$. mirabilis M13) were similar to each other ( $\mathrm{p}>0.5)$ and that the $\mathrm{K}_{\mathrm{k}} \mathrm{s}$ for the two human isolates $(E$. coli
H40, P. mirabilis $\mathrm{H1}$ ) were also similar to each other $(\mathrm{p}>0.5)$. The three mouse isolates appeared to be killed at slower rates than the two human isolates (table). These differences were not statistically significant when an analysis of variance was used to compare all five strains simultaneously but individually $(\mathrm{p}>0 \cdot 1)$; however, when the results obtained with the three mouse isolates and the two human isolates were pooled into two separate groups, the difference between the mouse and human isolates was significant $(\mathrm{p}<0 \cdot 05)$.

\section{In vivo clearance of $E$. coli $M 14$ and $A-D M S$ and $P$.} mirabilis M13 by liver, spleen and kidneys

The persistence of E. coli M14 and A-D M5 and $P$. mirabilis M13 after i.v. injection was monitored as the numbers of viable bacteria in the liver, spleen and kidneys (fig. 4) during a 48-h period. All livers, spleens and kidneys appeared grossly normal at each time throughout this assay and there were no

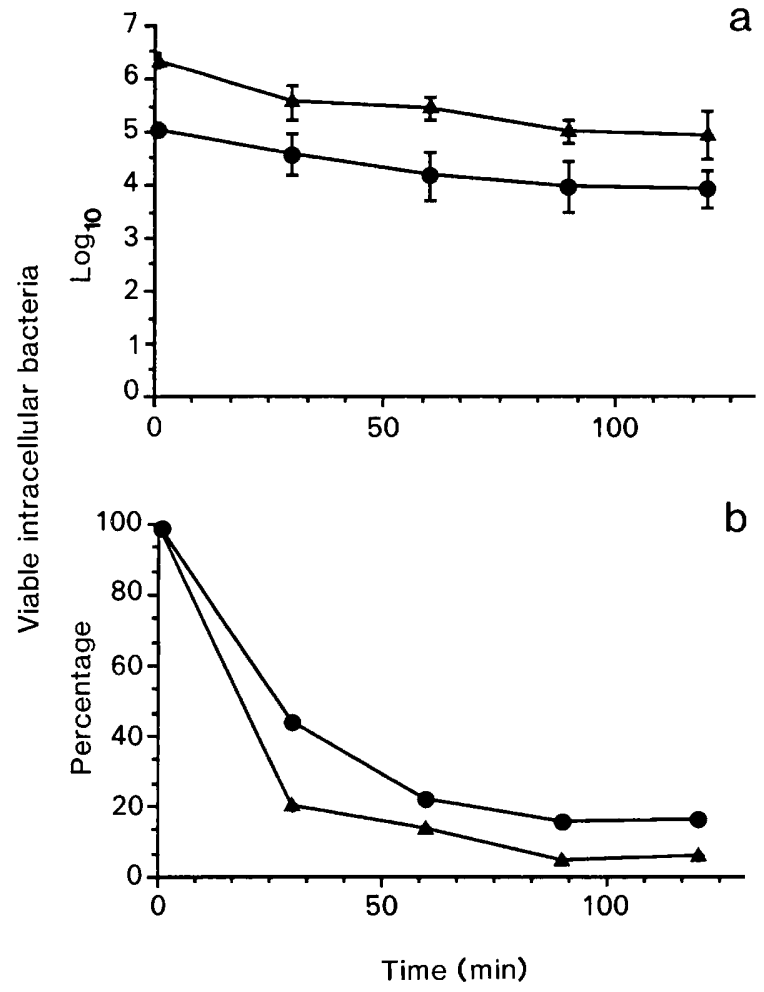

Fig. 3. In-vitro intracellular killing of $E$. coli $\mathrm{H} 40(\boldsymbol{\Delta})$ and $P$.

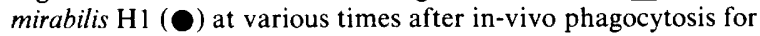
$3 \mathrm{~min}$ by mouse peritoneal exudate cells. (a) Numbers of viable bacteria recovered from $(6-8) \times 10^{6}$ peritoneal exudate cells. (b) Percentage of viable intracellular bacteria (number of bacteria recovered at time $0=100 \%$ ). Results are expressed as means, $\mathrm{bar}=\mathrm{SEM}$. 

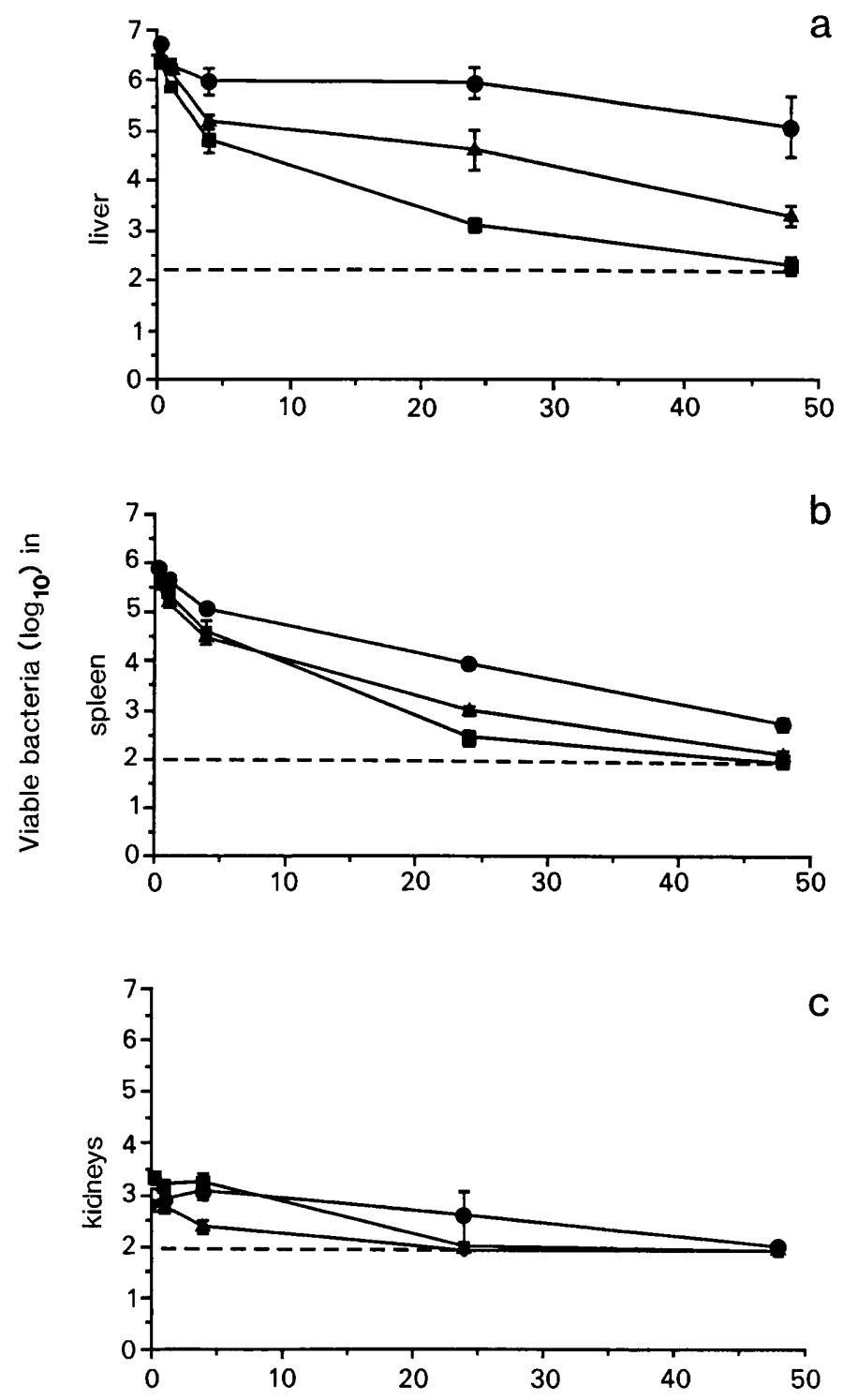

Time (h) after i.v. injection

Fig. 4. Persistence of E. coli M14 (A) and A-D M5 ( $\mathbf{0})$ and P. mirabilis M13(O) in (a) liver, (b) spleen and (c) kidneys of mice killed at various times after i.v. injection of bacteria. The data are expressed as the mean total numbers of bacteria per tissue, bar $=\mathrm{SEM}$. The dotted line indicates the lower limit of detection of the assay.

signs of abnormal pathology. A general observation was that $E$. coli M14 and A-D M5 were eliminated more efficiently from the reticulo-endothelial system than was $P$. mirabilis M13 (fig. 4). Mice given $P$. mirabilis M13 by i.v. injection looked ill and had ruffled fur $24 \mathrm{~h}$ after injection, but then appeared to recover. In contrast, mice given $E$. coli M14 or A-D M5 remained visibly healthy throughout the experiment. In preliminary experiments, $10^{8} \mathrm{cfu}$ of
E. coli M14 or A-D M5 or P. mirabilis M13 were injected i.p. into separate groups of 20 mice; 2 $(10 \%)$ of 20 mice given $P$. mirabilis M13 died at $24 \mathrm{~h}$ in each of two experiments (a total of 4 deaths in 40 mice). None of 40 mice given E. coli M14 or A-D M5 died.

After i.v. injection, the number of viable $P$. mirabilis M13 in the liver decreased approximately 10 -fold from $15 \mathrm{~min}$ to $48 \mathrm{~h}$ after injection; during 
the same period, the number of viable $E$. coli $\mathrm{M} 14$ and A-D M5 in the liver decreased 1000 -fold and 10000 -fold, respectively (fig. 4a). The number of viable $P$. mirabilis M13 was significantly greater ( $<<0.01)$ than the number of E. coli M14 or A-D M5 at 1, 4, 24 and $48 \mathrm{~h}$ after injection. Furthermore, $E$. coli M14 appeared to be eliminated from the liver less readily than $E$. coli A-D M5, and this was significant $(\mathrm{p}<0.01)$ at 4 and $24 \mathrm{~h}$ after injection. At $48 \mathrm{~h}$, the numbers of viable $E$. coli in the liver were below the limit of detection of the assay in 6 $(75 \%$ ) of 8 mice that received strain A-D M5 but in none that had received strain M14, indicating that $E$. coli A-D M5 was cleared more efficiently than $E$. coli M14 by this time, although the numbers of viable bacteria were not significantly different. The relative persistence of bacteria in the liver was $P$. mirabilis M13 more than $E$. coli M14 more than $E$. coli A-D M5

Bacterial elimination from the spleen paralleled that from the liver (fig. 4b). At all times from $1 \mathrm{~h}$ after bacterial injection, the numbers of $P$. mirabilis M13 cells in the spleen were greater than the numbers of $E$. coli M14 or A-D M5 $(\mathrm{p}<0.01$ compared with $E$. coli M14 at 1, 4, 24 and $48 \mathrm{~h}$ and $E$. coli A-D M5 at 24 and $48 \mathrm{~h} ; \mathrm{p}<0.05$ compared with $E$. coli A-D M5 at 1 and 4 h). Greater numbers of $E$. coli M14 than of $E$. coli A-D M5 were recovered from the spleen, mimicking the persistence of these strains in the liver. The numbers of viable $E$. coli $\mathrm{M} 14$ cells in the spleen were greater than those of $E$. coli A-D M5 (p<0.01) at $24 \mathrm{~h}$. At $48 \mathrm{~h}$, the numbers of viable $E$. coli M14 and A-D M5 cells in the spleen were below the limit of detection of the assay in $3(38 \%)$ of 8 and $7(88 \%)$ of 8 mice, respectively, again indicating that $E$. coli M14 persisted to a greater extent than $E$. coli A-D M5.

Bacterial persistence in the kidneys was also monitored (fig. 4c) with the same overall results found with the spleen and liver, i.e., $P$. mirabilis M13 persisted more than E. coli M14, and E. coli M14 more than E. coli A-D M5. However, by the end of the 48-h assay, each of the three strains appeared to be eliminated from the kidneys, with viable bacteria detected in the kidneys of only one of eight mice given $P$. mirabilis M13.

In-vivo clearance of E. coli $\mathrm{H} 40$ and P. mirabilis $\mathrm{HI}$ by the liver, spleen and kidneys

All livers, spleens and kidneys appeared grossly normal throughout this assay and there were no signs of abnormal pathology. Again, a general observation was that the $P$. mirabilis strain persisted in the reticulo-endothelial system to a greater extent than the $E$. coli strain (fig. 5). Furthermore, mice given $P$. mirabilis $\mathrm{H} 1$ looked ill and had ruffled fur. In the first experiment, 20 mice were given $P$. mirabilis $\mathrm{H} 1$, with the intention of killing groups of four at $15 \mathrm{~min}$ and $1,4,24$ and $48 \mathrm{~h}$ after injection. However, four mice were dead at $24 \mathrm{~h}$, leaving only two mice available for assay at 24 and $48 \mathrm{~h}$. Therefore, in the replicate experiment, 24 mice were given $P$. mirabilis $\mathrm{H} 1$, and again 4 mice were dead $24 \mathrm{~h}$ after injection, but four mice were still available for assay at 24 and $48 \mathrm{~h}$ after injection. Thus, of a total of 44 mice given $P$. mirabilis $\mathrm{H} 1,8$ were dead at 24 h, i.e., $18 \%$ mortality. In contrast, mice given $E$. coli $\mathrm{H} 40$ appeared healthy throughout the $48 \mathrm{~h}$ experiment and none died.

After i.v. injection, the numbers of viable $P$. mirabilis $\mathrm{H} 1$ in the liver decreased approximately 100 -fold from $15 \mathrm{~min}$ to $48 \mathrm{~h}$ after injection; during the same period, the numbers of viable $E$. coli $\mathrm{H} 40$ in the liver decreased 100-fold (fig. 5a). However, the numbers of viable $P$. mirabilis $\mathrm{H} 1$ were significantly greater $(\mathrm{p}<0.01)$ than the numbers of $E$. coli $\mathrm{H} 40$ at 1 and $4 \mathrm{~h}$ after injection. Although the numbers of viable $P$. mirabilis $\mathrm{H} 1$ in the liver remained greater than the numbers of viable $E$. coli $\mathrm{H} 40$ for the remainder of the 48-h assay, these differences were not statistically significant.

Differences in the numbers of viable $E$. coli $\mathrm{H} 40$ and $P$. mirabilis $\mathrm{Hl}$ were more noticeable in the spleen than in the liver (fig. 5b). The numbers of $E$. coli $\mathrm{H} 40$ in the spleen decreased more than 1000fold from $15 \mathrm{~min}$ to $48 \mathrm{~h}$ after injection, while the numbers of $P$. mirabilis $\mathrm{H} 1$ decreased over 10000 fold. At all time points, the numbers of $P$. mirabilis $\mathrm{H} 1$ in the spleen were greater than those of $E$. coli $\mathrm{H} 40(\mathrm{p}<0.01$ at $15 \mathrm{~min}$ and 1,4 and $24 \mathrm{~h}$, and $\mathrm{p}<$ 0.05 at $48 \mathrm{~h}$ ). In six of eight mice given $E$. coli $\mathrm{H} 40$ bacteria were not detected in the spleen at $48 \mathrm{~h}$, a phenomenon that was not observed with any of the six mice given $P$. mirabilis $\mathrm{H} 1$.

Persistence of $E$. coli $\mathrm{H} 40$ and $P$. mirabilis $\mathrm{H} 1$ in the kidneys was also monitored (fig. 5c) with the same overall result as noted with the spleen and liver, i.e., $P$. mirabilis $\mathrm{H} 1$ was eliminated less readily than $E$. coli $\mathrm{H} 40$. The numbers of $P$. mirabilis $\mathrm{H} 1$ in the kidneys were greater than those of $E$. coli $\mathrm{H} 40$ at nearly all time points throughout the assay ( $\mathrm{p} \leq$ 0.01 at $15 \mathrm{~min}$ and 1,4 and $24 \mathrm{~h}$ ). At the end of the 48-h assay, viable bacteria were detected in the kidneys of only two of eight mice given $E$. coli $\mathrm{H} 40$ and in four of six mice given $P$. mirabilis $\mathrm{H} 1$.

\section{Discussion}

This study has analysed the interactions of mouse 

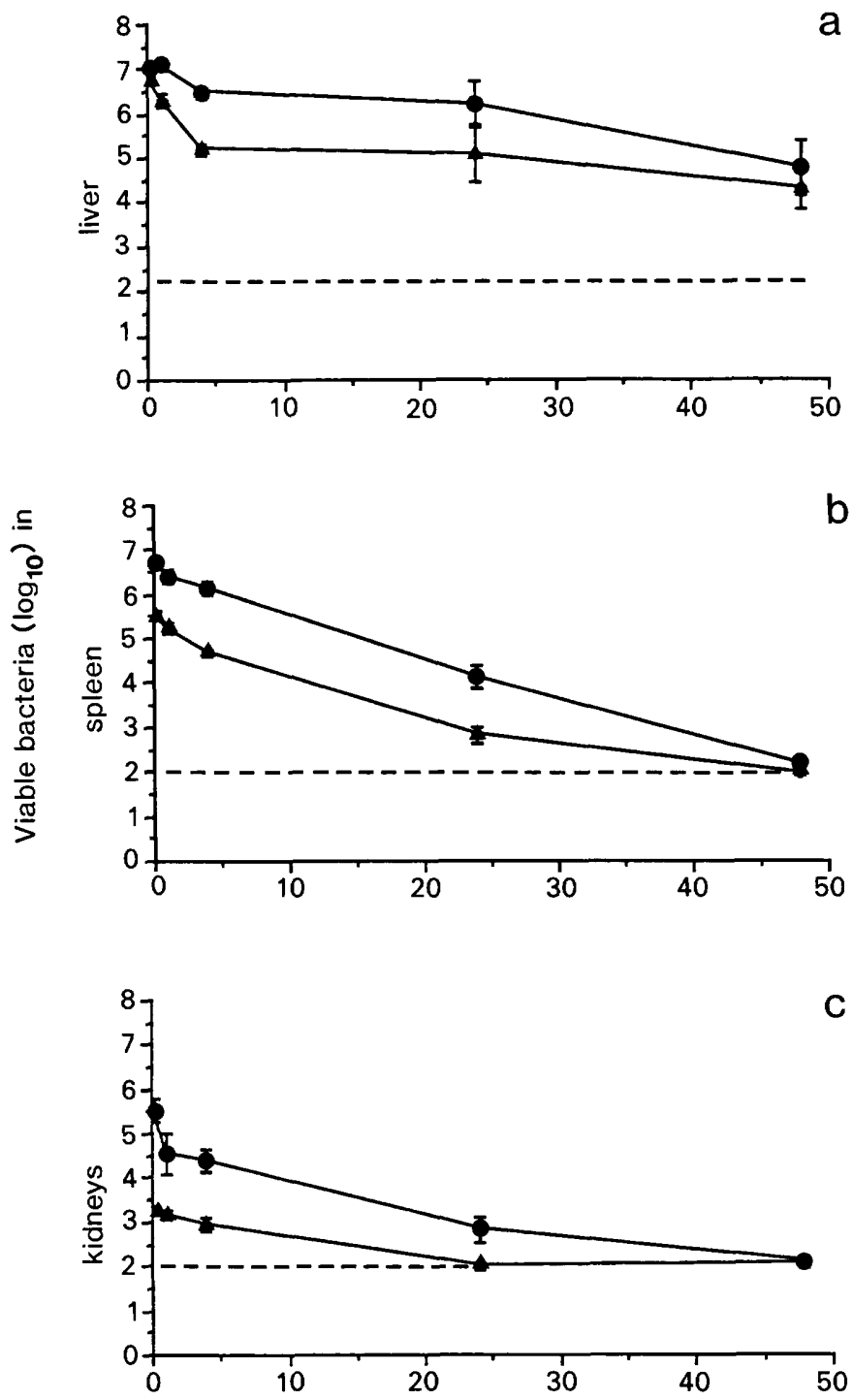

Time (h) after i.v. injection

Fig. 5. Persistence of E. coli $\mathbf{H} 40(\mathbf{\Delta})$ and $P$. mirabilis $\mathrm{Hl}(\boldsymbol{O})$ in (a) liver, (b) spleen and (c) kidneys of mice killed at various times after i.v. injection of bacteria. The data are expressed as the mean total numbers of bacteria per tissue, bar $=\mathrm{SEM}$. The dotted line indicates the lower limit of detection of the assay.

peritoneal exudate cells with five strains of enterobacteria, three of $E$. coli and two of $P$. mirabilis. Initial experiments were with three mouse isolates, E. coli M14 and A-D M5 and P. mirabilis M13; although all three strains were killed intracellularly at similar rates, $P$. mirabilis M13 was ingested less readily than either $E$. coli strain. In subsequent invivo experiments, $P$. mirabilis $\mathrm{M} 13$ was cleared less readily by liver and splenic phagocytes than $E$. coli M14 or A-D M5. Thus, the extent of phagocytic uptake and not the rate of intracellular killing was associated with the relative inability of tissue phagocytes to eliminate $P$. mirabilis $\mathrm{M} 13$ from the liver and spleen. To expand and confirm these observations, two human isolates (E. coli $\mathrm{H} 40$ and $P$. mirabilis $\mathrm{H} 1$ ) were tested subsequently with similar results.

To study phagocytic uptake and intracellular killing, peritoneal exudate cells were allowed to ingest bacteria in vivo. The peritoneal exudate cells 
were then harvested and stained with acridine orange to assess phagocytic uptake visually. Nearly all intracellular bacteria appeared viable at this time, although the bacteria were unevenly distributed among phagocytes. The total numbers of peritoneal exudate cells were similar for each mouse and the individual inocula for each of the five bacterial strains contained similar numbers of bacteria, but there were always fewer intracellular $P$. mirabilis cells visible than $E$. coli cells immediately after the peritoneal exudate cells were harvested. It was possible to distinguish blindly leucocyte suspensions containing $P$. mirabilis from those containing $E$. coli because there appeared to be 10 - to 100 -fold fewer intracellular $P$. mirabilis than $E$. coli. After $3 \mathrm{~min}$ for phagocytosis in vivo, calculations of the average number (obtained from bacterial cultures) of viable bacteria per leucocyte were reproducible for each strain; this ratio was significantly lower for the two $P$. mirabilis strains compared with each of the three $E$. coli strains (table). We concluded, as did Ofek and Sharon, ${ }^{9}$ that this ratio represented a numerical index of the extent of phagocytosis. Thus, the bacteria-toleucocyte ratios obtained immediately after phagocytic uptake could be interpreted to indicate that $E$. coli was ingested more readily than $P$. mirabilis, an interpretation that was consistent with microscopic visualisation with acridine orange staining.

The phagocytic index for the human $E$. coli $\mathrm{H} 40$ strain was somewhat less than those for the two mouse $E$. coli strains suggesting that the human $E$. coli was not phagocytosed as readily as either mouse strains. The human $E$. coli strain also had a higher $\mathrm{K}_{\mathrm{k}}$ value, indicating that it was not killed as readily as either of the two mouse strains. These observations might be explained by the hypothesis that mice respond differently to indigenous (mouse) and non-indigenous (human) isolates. ${ }^{11}$ However, these differences were not statistically significant.

We cannot explain the lower phagocytic uptake of the two $P$. mirabilis strains compared to the three $E$. coli strains. Because $E$. coli M14 and P. mirabilis M13 were isolated originally from the intestinal flora of Swiss-Webster mice, it is likely that the mice had antibodies to both species; furthermore, because both species share the common enterobacterial antigen, antibody to one species could be expected to cross-react with the other species. Therefore, it is unlikely that the presence or absence of antibody played a major role in the differences in in-vivo phagocytic uptake between $E$. coli and $P$. mirabilis. There is also evidence that certain types of fimbriae on $E$. coli and $P$. mirabilis enhance susceptibility to phagocytosis by polymorphonu- clear leucocytes, whereas other types of fimbriae have no opsonic activity. ${ }^{12-15}$ Although fimbriae were not typed in this study, the presence of fimbriae could not explain enhanced phagocytosis, because their presence on $P$. mirabilis $\mathrm{M} 13$ and $\mathrm{H} 1$ was associated with decreased phagocytic activity.

The rate of decrease in the numbers of viable intracellular bacteria appeared to be similar for all five strains tested (figs. $1 \mathrm{a}$ and $3 \mathrm{a}$ ) and the $\mathrm{K}_{\mathrm{k}}$ s were also similar, although the two human isolates appeared to be killed somewhat faster than the three mouse isolates. For the three mouse strains, an average of $14-17 \%$ of the intracellular bacteria remained viable at the end of the 2-h assay, reflecting an average of $\log _{10} 5 \cdot 3 E$. coli $\mathrm{M} 14, \log _{10}$ $5 \cdot 6$ E. coli A-D M5, and at least 10-fold fewer (i.e., $\left.\log _{10} 4 \cdot 0\right)$ viable $P$. mirabilis M13 per $(6-8) \times 10^{6}$ peritoneal exudate cells. A similar pattern was noted for $E$. coli $\mathrm{H} 40$ and $P$. mirabilis $\mathrm{H} 1$. The relatively fewer numbers of viable intracellular $P$. mirabilis $\mathrm{M} 13$ and $\mathrm{H} 1$ recovered at the end of this assay reflected their relatively lower numbers at the beginning of the assay. The lower numbers of $P$. mirabilis $\mathrm{M} 13$ and $\mathrm{H} 1$ at the beginning of the assay of in-vitro intracellular killing appeared to be due to the relative lack of phagocytic uptake of both strains compared with the three $E$. coli strains. Although the majority of intracellular bacteria were killed during the assay, substantial numbers of viable intracellular bacteria were recovered at its conclusion. Acridine orange staining of peritoneal exudate cells confirmed that, although the majority of the intracellular bacteria appeared dead, viable intracellular bacteria were easily detectable at this time:

We attempted to compare our results of intracellular killing of $E$. coli and $P$. mirabilis with results reported by others. There is evidence that the rate of intracellular killing of $S$. typhimurium by mononuclear phagocytes can vary depending upon the strain of mouse used and upon the conditions of phagocytosis, i.e. in vivo or in vitro. Using methodology similar to ours, van Dissel et al. ${ }^{8}$ reported that the average $\mathrm{K}_{\mathrm{k}}$ for $S$. typhimurium was 0.031 / min with C57BL/ 10 mice and $0.055 / \mathrm{min}$ with CBA mice. Also, after phagocytosis in vivo or in vitro, the average $\mathrm{K}_{\mathrm{k}}$ for $S$. typhimurium varied from $0.055 /$ min to $0 \cdot 020 / \mathrm{min}$ with peritoneal exudate cells from CBA mice. This variability may not be typical because macrophages from C57BL/10 mice and CBA mice killed L. monocytogenes and Staphylococcus aureus with equal efficiency; here, the average $\mathrm{K}_{\mathrm{k}} \mathrm{s}$ for L. monocytogenes and Staph. aureus with macrophages from C57BL/10 and CBA mice were $0.022 / \mathrm{min}$ and $0.023 / \mathrm{min}$ for Staph. aureus, and 
$0.033 / \mathrm{min}$ and $0.032 / \mathrm{min}$ for $L$. monocytogenes. Similar comparisons of the effects of various test conditions on intracellular killing are not available for $E$. coli and $P$. mirabilis. The most germane comparison of our data with other information in the literature might be obtained from van Dissel et $a .^{8}$ who reported that, after in-vivo phagocytosis in the peritoneal cavity of Swiss mice (the strain used in the present study), the average $\mathrm{K}_{\mathrm{k}}$ for $S$. typhimurium was $0 \cdot 049 / \mathrm{min} . \mathrm{K}_{\mathrm{k}} \mathrm{s}$ for five less pathogenic enterobacterial strains in our study were $0.016-0.029 / \mathrm{min}$. Therefore, as expected, each of these five strains appeared to be killed at a similar rate as has been reported for $S$. typhimurium or $L$. monocytogenes, two species known to survive and even replicate within macrophages. ${ }^{1-3}$ Of interest, each of the five enterobacterial strains used in this study appeared to be killed at a rate similar to that reported for Staph. aureus, ${ }^{8}$ a species considered to have some ability for intracellular survival within macrophages. ${ }^{16-18}$ Some investigators similarly claim that bacteria in the genus Escherichia also have an ability for facultative intracellular parasitism. ${ }^{2}$

To determine if our results for phagocytosis and in-vitro intracellular killing could be correlated with in-vivo killing by reticulo-endothelial phagocytes, the five test strains were injected i.v. into separate groups of mice and viable bacteria were counted in the liver, spleen and kidneys at $15 \mathrm{~min}$ and $1,4,24$ and $48 \mathrm{~h}$ after injection. This was done because the kinetics of persistence of viable bacteria in the liver and spleen can be used to provide information about the functional state of macrophages from the liver (Kupffer cells) and, to a lesser extent, from the spleen. ${ }^{1,19}$ As a caveat, it should be mentioned that, after i.v. injection of bacteria, the initial phase of infection is associated primarily with phagocytosis by resident tissue macrophages but bacteria escaping initial clearance may be phagocytosed by polymorphonuclear leucocytes attracted to a site of infection. ${ }^{20-22}$

The results of these in-vivo assays indicated that a greater number of $P$. mirabilis M13 than of the two mouse $E$. coli isolates persisted in the reticuloendothelial system; similarly, a greater number of $P$. mirabilis $\mathrm{H} 1$ than the human $E$. coli $\mathrm{H} 40$ isolate persisted in the reticulo-endothelial system. These findings were evident in the liver and spleen, but were also supported by the results with the kidneys. Therefore, it was not surprising that the two $P$. mirabilis strains were associated with mortality in mice, whereas there were no deaths with $E$. coli strains. The comparatively slow rates of in-vivo elimination of $P$. mirabilis were associated with the observation that the $P$. mirabilis strains were phagocytosed less readily by peritoneal macrophages. Because the $K_{k}$ s of all five enterobacterial strains were similar, it seemed reasonable to speculate that the relative virulence of the $P$. mirabilis strains compared with the $E$. coli strains might be due to an antiphagocytic property of $P$. mirabilis and not to an increased ability of $P$. mirabilis to survive within mononuclear phagocytes. However, it should be noted that phagocytic uptake was calculated following phagocytosis by peritoneal macrophages that had been elicited with proteose peptone, and intracellular killing was assesed following in-vitro incubation of peritoneal exudate cells. We cannot be certain that similar kinetics of phagocytic uptake and intracellular killing occurred in vivo with splenic, hepatic or renal phagocytes. However, the in-vitro results were consistent with the in-vivo findings.

There is substantial evidence that tissue mononuclear phagocytes play a key role in the transport of normal intestinal bacteria and inert particles. ${ }^{3,6,23}$ The present experiments attempted to characterise the interactions of five strains of normal enterobacteria with mononuclear phagocytes. These strains appeared to have differing abilities for phagocytic uptake but similar rates of intracellular killing, and a small but noticeable proportion appeared capable of intracellular survival for at least $2 \mathrm{~h}$ within mononuclear phagocytes. This small incidence of intracellular survival may be critical. There is a repeated observation that, if a bacterial strain colonises the intestinal tract at a high concentration of $\log _{10} 10-11 / \mathrm{g}$ of intestinal contents, only $c$. $\log _{10} 1-2$ viable bacteria translocate to the draining mesenteric lymph nodes. ${ }^{24-28}$ The results of this study also suggested that two $P$. mirabilis strains were more virulent than each of three $E$. coli strains. This relative virulence of $P$. mirabilis appeared to depend more on the rate of phagocytic uptake by mononuclear phagocytes than on the rate of intracellular survival within these phagocytes. These results should provide the basis for further studies designed to clarify the virulence factors associated with the in-vivo infectivity of various strains of enterobacteria.

This work was supported in part by Public Health Service grants AI23484 (to C.L.W.) and AI22374 (to R.D.N.) from the National Institutes of Health. We thank G. Sedgewick for assistance with photography. S. L. Erlandsen for assistance with electronmicroscopy, and Diane Bierman for assistance with microbiological assays. 


\section{REFERENCES}

1. Leijh $\mathbf{P} \mathbf{C} \mathbf{J}$, van Furth $\mathbf{R}$, van Zwet $\mathbf{T} \mathrm{L}$. In-vitro determination of phagocytosis and intracellular killing by polymorphonuclear and mononuclear phagocytes. In: Weir D $\mathbf{M}$ (ed) Handbook of experimental immunology, 4th edn, vol. 2, chapter 46: Cellular immunology. Oxford, Blackwell Scientific Publications. 1986.

2. Moulder J W. Comparative biology of intracellular parasitism. Microbiol Rev 1985; 49: 298-337.

3. Wells C L, Maddaus M A, Simmons R L. Proposed mechanisms for the translocation of intestinal bacteria. Rev Infect Dis 1988; 10: 958-979.

4. Racz P, Tenner K, Mero E. Experimental listeria enteritis. I. An electron microscopic study of the epithelial phase in experimental listeria infection. Lab Invest 1972; 6 : 694-700.

5. Popiel I, Turnbull P C. Passage of Salmonella enteritidis and Salmonella thompson through chick ileocecal mucosa. Infect Immun 1985; 47: 786-792.

6. Wells C L, Maddaus M A, Erlandsen S L, Simmons R L. Evidence for the phagocytic transport of intestinal particles in dogs and rats. Infect Immun 1988; 56: 278 282.

7. Finegold S M, Baron E J. Bailey and Scott's diagnostic microbiology. St Louis, MO, The CV Mosby Co. 1986 : 914.

8. van Dissel J T, Leijh P C J, van Furth R. Differences in initial rate of intracellular killing of Salmonella typhimurium by resident peritoneal macrophages from various mouse strains. $J$ Immunol 1985 ; 134 : $3404-$ 3410 .

9. Ofek I, Sharon N. Lectinophagocytosis: a molecular mechanism of recognition between cell surface sugars and lectins in the phagocytosis of bacteria. Infect Immun $1988 ;$ 56: 539-547.

10. Pantazis C G, Kniker W T. Assessment of blood leukocyte microbial killing by using a new fluorochrome microassay. J Reticuloendothel Soc 1979; 26: 155-169.

11. Berg R D, Savage D C. Immune responses of specific pathogen-free and gnotobiotic mice to antigens of indigenous and non-indigenous microorganisms. Infect Immun 1975; 11 : 320-329.

12. Bjorksten B, Wadstrom T. Interaction of Escherichia coli with different fimbriae and polymorphonuclear leukocytes. Infect Immun 1982; 38: 298-305.

13. Silverblatt F J, Ofek I. Influence of pili on the virulence of Proteus mirabilis in experimental pyelonephritis. In: Kass E, Brumfitt W (eds) Infections of the urinary tract. Proceedings of the Third International Symposium on Pyelonephritis, London. Chicago, Chicago University Press. 1979 : 49-59.
14. Silverblatt F J, Ofek I. Influence of pili on the virulence of Proteus mirabilis in experimental hematogenous pyelonephritis. J Infect Dis 1978; 138 : 664-667.

15. Silverblatt F J, Dreyer J S, Schauer S. Effect of pili on susceptibility of Escherichia coli to phagocytosis. Infect Immun 1979; 24: 218-223.

16. Mandell G L. Catalase, superoxide dismutase, and virulence of Staphylococcus aureus. In vitro and in vivo studies with emphasis on staphylococcal-leukocyte interactions. J Clin Invest $1975 ; \mathbf{5 5}$ : $561-566$.

17. Rogers D E, Tompsett $\mathbf{R}$. The survival of staphylococci within human leukocytes. J Exp Med 1952; 95: 209230.

18. Verbrugh H A. Phagocytosis and destruction of Staphylococcus aureus. Vet $Q 1981 ; 3: 91-97$.

19. Slijivic V S, Warr G W. Measurement of phagocytic function in vivo. In: Herscowit $\mathrm{H} \mathrm{B}$, Holden $\mathrm{H} \mathrm{T}$, Bellanti J A, Ghaffar A (eds) Manual of macrophage methodology. Collection, characterization, and function. New York, Marcel Dekker, Inc. 1981 : 447-457.

20. Czuprynski C J, Hensen P M, Campbell P A. Killing of Listeria monocytogenes by inflammatory neutrophils and mononuclear phagocytes from immune and nonimmune mice. J Leukoc Biol 1984; 35: 193-208.

21. Densen P, Mandell G L. Phagocyte strategy vs. microbial tactics. Rev Infect Dis 1980; $2: 817$.

22. Mandell T E, Cheers C. Resistance and susceptibility of mice to bacterial infection: histopathology of listeriosis in resistant and susceptible strains. Infect Immun 1980; 30: $851-861$.

23. Harmsen A G, Muggenburg B A, Snipes M B, Bice D E. The role of macrophages in particle translocation from lungs to lymph nodes. Science $1985 ; 230$ : 1277-1280.

24. Maejima K, Deitch E A, Berg R D. Bacterial translocation from the gastrointestinal tracts of rats receiving thermal injury. Infect Immun 1984; 43: 6-10.

25. Steffen E, Berg R D. Relationship between cecal population levels of indigenous bacteria and translocation to mesenteric lymph nodes. Infect Immun 1983; 39: 12521259.

26. Wells C L, Maddaus M A, Reynolds C M, Jechorek R P, Simmons R L. The role of the anaerobic flora in the translocation of aerobic and facultatively anaerobic intestinal bacteria. Infect Immun 1987; 55: 2689-2694.

27. Wells C L, Jechorek R P, Maddaus M A. The translocation of intestinal facultative and anaerobic bacteria in defined flora mice. Microb Ecol Health Dis 1988; 1: 227-235.

28. Wells C L, Jechorek R P, Maddaus M A, Simmons R L. The effects of clindamycin and metronidazole on the intestinal colonization and translocation of enterococci in mice. Antimicrob Agents Chemother 1988; 32: 17691775 . 